Review

\title{
Genomic Analysis for Citrus Disease Detection
}

Mohamed Abutineh ${ }^{1}$, Nicholas Pizzo ${ }^{1}$, Nicholas Nifakos ${ }^{1}$, Xiao-Lu Jin ${ }^{1}$, John M Harlin ${ }^{2}$, Xing-Hai Zhang ${ }^{1, *}$

1. Department of Biological Sciences, Florida Atlantic University, Boca Raton, FL 33431, USA; E-Mails: mabutineh2016@fau.edu; npizzo2016@fau.edu; nnifakos@fau.edu; xjin@health.fau.edu; xhzhang@fau.edu

2. Penta5, USA, Sarasota, FL 34234, USA; E-Mail: max.harlin43@gmail.com

* Correspondence: Xing-Hai Zhang; E-Mail: xhzhang@fau.edu

Academic Editor: Yuri Shavrukov

Special Issue: Plant Genetics and Gene Analysis

OBM Genetics

2021, volume 5 , issue 1

doi: :10.21926/obm.genet.2101124
Received: December 26, 2020

Accepted: February 05, 2021

Published: February 18, 2021

\begin{abstract}
Citrus is an important group of globally produced fruit crops, holding great economic, cultural, and health value. Belonging to the Rutacaeae family, the genus Citrus includes some of the most iconic and widely appreciated variants of fruits such as the orange, lemon, lime, grapefruit, and tangerine. The spread of various diseases threatens the worldwide production of citrus fruit crops. Diseases such as Asiatic citrus canker, citrus tristeza virus, citrus leprosis, and especially citrus greening disease (also known as Huanglongbing) cause various symptoms harmful to plant growth and fruit production, inflicting tremendous economic damages. Advancements in genetic analysis technologies have offered new tools to investigate the molecular mechanisms underlining these diseases. In this review, we briefly overview the utility of genetic analysis in detection and monitoring of citrus disease-causing pathogens. We then focus our discussion on one of the most damaging citrus diseases, citrus greening disease (Huanglongbing). Genomic and gene expression analysis of citrus plants and their disease-causing microbes, along with tissue
\end{abstract}

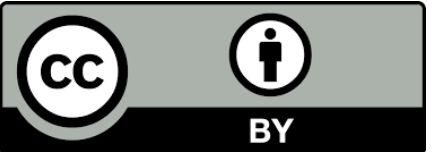

(C) 2021 by the author. This is an open access article distributed under the conditions of the Creative Commons by Attribution License, which permits unrestricted use, distribution, and reproduction in any medium or format, provided the original work is correctly cited. 
and cellular structural imaging, has demonstrated the potential allowing early pathogen detection and disease monitoring. These will eventually help to develop effective treatments to protect and promote citrus crop production.

\section{Keywords}

Candidatus Liberibacter asiaticus (CLas); citrus greening disease (Huanglongbing, HLB); clementine (Citrus $x$ clementina); key lime (Citrus $\times$ aurantiifolia); lemon (Citrus $\times$ limon); persian lime (Citrus $\times$ latifolia); sweet orange (Citrus $\times$ sinensis); quantitative polymerase chain reaction (qPCR), scanning electron microscopy (SEM)

\section{Citrus Crops}

The genus Citrus, belonging to the subfamily Aurantioideae of the Rutaceae family, encompasses some of the world's most widely available and consumed fruit crops [1]. These citrus plants develop large evergreen shrubs or small trees and produce economically important fruits such as clementine (Citrus $x$ clementina), lemon (C. $x$ limon), grapefruit (C. $x$ paradisi), limes (C. aurantifolia, $C . x$ latifolia), sweet orange $(C . x$ sinensis) and tangerine or mandarin (C. $x$ reticulata) (as summarized in supplementary Table 1 by [2]. Among these species, oranges contributed more than half of over 130 million metric tons of citrus fruits in 2018-2019 worldwide [3]. Orange juice production has become an important dietary staple for its capacity to provide numerous nutritional benefits.

Table 1 Genomic data of several major Citrus species retrieved from citrusgenomedb.org.

\begin{tabular}{lllll}
\hline Species & Common name & Ploidy & Chromosome number & Genome size* \\
\hline C. x limon & Lemon & N/A & N/A & N/A \\
C. x paradisi & Grapefruit & N/A & N/A & N/A \\
C. x aurantiifolia & Key lime & N/A & N/A & N/A \\
C. x sinensis & Sweet orange & Diploid & $2 \mathrm{n}=18$ & $380 \mathrm{Mbp}$ \\
C. x reticulata & Tangerine & Diploid & $2 \mathrm{n}=18$ & $\sim 370 \mathrm{Mbp}$ \\
C. x maxima & Pomelo & Diploid & $2 \mathrm{n}=18$ & $380 \mathrm{Mbp}$ \\
C. x ichangensis & Papeda & Diploid & $2 \mathrm{n}=18$ & $391 \mathrm{Mbp}$ \\
C. x clementina & Clementine & Diploid & $2 \mathrm{n}=18$ & $370 \mathrm{Mbp}$ \\
C. medica & Citron & Diploid & $2 \mathrm{n}=18$ & $407 \mathrm{Mbp}$ \\
\hline
\end{tabular}

* Mbp: $10^{6}$ base pairs

While citrus plants can be grown in most countries, ideal growing conditions are found along the equator within the tropic and subtropical regions without freezing winters, because citrus is cold sensitive. Citrus species have various origins; sweet oranges and mandarins (Citrus $x$ reticulata) are 
believed to have originated from China and lemons (Citrus $x$ limon) from India [4]. New evidence suggests that other citrus species originated from Australia and surrounding areas [4, 5].

Many commercial citrus fruits were originated from hybridizations between Citrus species (therefore the use of $x$ in their scientific names) that were then selected and cultivated over the last few thousand years $[2,6]$. The principal producers in citrus fruits are Brazil, China, the United States (mainly in Florida, California and Texas), India, Spain, and Mexico [7]. In the United States, the majority of fresh citrus produce is grown in California, while most processed citrus production occurs in Florida [8]. Byproducts like peels and seeds from fruit processing are used in animal feed and fuel production [9]. In Florida alone, the citrus industry generates economic impact of nearly $\$ 9$ billion per year, produces $77 \%$ of citrus juices in the US and employs nearly 76,000 people [10]. Citrus is an integral component of Florida's agricultural industry, having accounted for about $21 \%$ of farm cash receipts in 2005 alone [11].

Citrus fruits are well-acclaimed for their nutritional content and health benefits. The fruits contain little fat or protein, but have an abundance of carbohydrates such as fiber and simple sugars. They possess a wide array of micronutrients vital to human health, such as folate, riboflavin, thiamin, vitamin B6, vitamin C, potassium, calcium, magnesium, phosphorus, pantothenic acid, and copper [12]. Extracts from citrus fruit have been found to possess bioactive phenolic compounds such as hydroxycinnamic acids and flavanone glycosides [13]. Flavanones are an especially important group of phenolic compounds that have been reported to have various health benefits such as reducing the risk of coronary heart disease and other degenerative diseases due to their anti-oxidant, anti-inflammatory, anti-fungal and anti-carcinogenic properties [14, 15]. Citrus fruits have also assumed an important role in some cultures as an alternative medicine for treating bacterial and fungal infections and cancer [16].

\section{Citrus Genomics}

The importance of citrus fruits, both economically and nutritionally, therefore, rationalizes the need for more intensive research and development of citrus genome sequencing techniques and resources. The International Citrus Genome Consortium has set forth some of these resources that are available publicly, including Expressed Sequence Tag (EST) databases, genetic linkage maps, and other tools to further develop functional genomics, which has led to sequencing the whole citrus genomes $[2,4,17]$. Genomic sequencing and analysis have greatly enhanced our knowledge of citrus biology. For example, it is now well accepted that many, if not all, citrus species grown today are likely to have diverged from a single ancestor species Poncirus trifoliata. Environmental changes in the late Miocene era were associated with variations resulting in citrons (Citrus $x$ medica), pomelos (C. maxima), mandarins (C. $x$ reticulata), kumquats (C. $x$ japonica), and papeda (C. $x$ micrantha) $[2,18]$. Most Citrus varieties existing today arose from these original varieties through interspecific hybridization, followed by selection and cultivation [6].

The Citrus Genome Database (citrusgenomedb.org) is a free web portal that provides current status on citrus genomics. The genomes of at least 7 species and 58 citrus accessions have been sequenced: Clementine ( $C$. $x$ clementina), sweet orange ( $C$. sinensis, $\mathrm{cv}$. Ridge Pineapple and $\mathrm{cv}$. Valencia), pomelo (C. $x$ maxima), Ichang papeda (C. $x$ ichangensis, cv. XJC), citron (C. $x$ medica (cv. X2), and mandarin 
orange ( $C$. $x$ reticulata, $\mathrm{cv}$. WM01). Those diploids $(2 n=2 x=18)$ have a genome size ranging from 370 million base pairs (Mbp) to 407 Mbp per haploid (Table 1; [19-22]).

\section{Sequencing Orange Genomes}

The International Citrus Genome Consortium intended to have the sweet orange Citrus $x$ sinensis $\mathrm{cv}$. Ridge Pineapple (diploid) as the first citrus genome to be sequenced. However, difficulties with genome assembly arose due to complications associated with heterozygosity $[17,22]$. To mitigate assembly errors and ensure a more accurate genome sequence, a haploid line originating from Citrus $x$ clementina cv. Nules (a hybrid Clementine orange) was selected for whole-genome sequencing due to its pathological fitness and homozygosity [23]. The most accurate Sanger sequencing method was used $[2,24]$. As a result, the sequence of this line of $C . x$ clementina became the first reference genome for the Citrus genus.

Subsequently, new sequencing technology such as the highly sensitive and high through-put 454 pyrosequencing was used to finally complete the genome sequencing of the diploid sweet orange (C. $x$ sinensis cv. Ridge Pineapple) to serve as another reference genome for citrus plants. However, as anticipated, the assembled genome of sweet orange had a higher degree of fragmentation than the haploid Clementine [17, 20, 22, 25]. Nonetheless, the availability of high coverage genome sequences of these citrus species (Table 1) offers unprecedented convenience and opportunities for functional genomics research as well as investigations of plant growth, plant-pathogen interactions and citrus diseases.

\section{Citrus Diseases}

Citrus is a perennial crop and encounters numerous pathogens during their life time, some of which can result in significant crop damages and economic loss. Here we briefly review several more prominent citrus diseases.

\subsection{Asiatic Citrus Canker}

Asiatic citrus canker is an injurious disease caused by the bacterium Xanthomonas axonopodis pv. citri (Xac). Citrus varieties in Florida are especially susceptible to the disease [26]. Infected plants display erumpent exoderm lesions, fruit drop and crop decline and death. As the bacteria proliferate within exoderm lesions on the leaf, stem or fruit, plants suffer more severe symptoms, often producing unmarketable fruit. When these lesions are exposed to moisture, the Xac bacteria can be more easily dispersed to neighboring citrus plants to spread Xac infection [26]. Wind-driven rain is the primary dispersal force that facilitates tree-to-tree transmission of the canker disease [27, 28]. For this reason, the hurricane season (June to November in the US) is considered an active period for the spread of citrus canker. The wide-ranging dispersal of the Asian citrus leafminer (Phyllocnistis citrella Stainton) insect in several Florida citrus nurseries as discovered in 1993 has only worsened the spread of the bacteria. The leafminer feeds on citrus leaves, creating wounds and increasing the likelihood of Xac 
infection. Human activities handling infected plant materials also contribute to long distance spread $[26,29]$.

Currently, there is no effective treatment for canker disease. Integrated measures such as the use of disease-free nursery stock, replacement of vulnerable citrus materials with more resistant ones, the establishment of windbreaks or fences to negate airborne pathogen spread, and insecticides/copper sprays all manage the disease with various successes and drawbacks [26, 28]. However, quarantine measures of eradicating infected trees along with surrounding trees are no longer enforced in Florida. Use of bacteriophages to combat Xac and other plant diseases [30-32] has shown some success and demonstrated a new approach to control bacterial diseases. The genomes of several Xac strains have been sequenced, one of which is summarized in Table 2. Availability of the genome sequences has greatly facilitated investigation of Xac pathogenicity and qPCR-based detection, to supplement other conventional methods of disease identification.

Table 2 Representative genomic data of four citrus disease-causing pathogens. Data retrieved from GenBank.

\begin{tabular}{lccc}
\hline Species* & Genome Type & Genome Assembly Size & Number of Genes \\
\hline $\begin{array}{l}\text { Xanthomonas axonopodis } \\
\text { citri } 306 \text { ) }\end{array}$ & DNA & $5.17 \times 10^{6} \mathrm{bp}$ & 4,374 \\
$\begin{array}{l}\text { Citrus tristeza virus } \\
\text { Citrus leprosis virus C }\end{array}$ & ssRNA & $19.3 \times 10^{3} \mathrm{nt}$ & 11 \\
Xylella fastidiosa (9a5c) & ssRNA & $13,731 \mathrm{nt}$ & 6 \\
\hline
\end{tabular}

*Note: Only one representative strain from each species is shown.

\subsection{Citrus Tristeza Virus (CTV)}

Citrus tristeza virus (CTV), also called quick decline disease, causes one of the most severe, destructive viral diseases of citrus plants. As a member of the Closterovirus genus (Closteroviridae family), CTV is one of the largest RNA viruses in terms of genome size. It is thought to have originated in China but is now found in most citrus-growing regions [European and Mediterranean Plant Protection Organization (EPPO) Global Database] . CTV appears to be Rutaceae family-specific, with the exception being some species of the genus Passiflora, as infection by inoculation in other species was unsuccessful [33]. Citrus scions grown on sour orange rootstock are highly susceptible to CTV. During 1930s to 1950s, CTV killed millions of citrus trees on sour orange rootstock around the world [33, 34]. The main vector of the disease is the brown citrus aphid (Toxoptera citricida) [35]. Symptoms of CTV disease include quick decline, leaf chlorosis, stem-pitting, foliage yellowing and small fruits. Measures used to control the spread of CTV include rouging citrus plants, integration of CTV-tolerant or resistant rootstocks, or 
cross-protection. The viral genomic sequence has been determined (Table 2 ) and can be used to design specific primers for detecting and monitoring CTV strains through RT-PCR.

\subsection{Citrus Leprosis}

Citrus leprosis is another viral citrus disease caused by Citrus leprosis virus C (CiLV; Rhabdoviridae family). This RNA virus is transmitted by the false spider mite (Brevipalpus spp.) and causes symptoms characterized by localized chlorotic lesions, necrotic rings, premature fruit drop, and early tree death [36]. The disease is a threat to the U.S. citrus industry because the vector mite is found within all U.S. citrus-producing regions. Visual identification by the symptoms of this disease is often difficult since they may be confused with other citrus diseases like citrus canker. This virus has a comparatively small genome size (Table 2). The use of electron microscopy and RT-PCR to amplify and sequence CiLV genome regions [37] can achieve a reliable diagnosis. Acaricide applications are considered an effective treatment, but acaricide-resistant Brevipalpus mites have been detected [38]. Other practices include pruning of infected branches, incorporation of windbreak plants to reduce mite dispersal, control of other Brevipalpus host weeds, and replanting infected orchards with healthy plants [39]. All these measures mainly target the vector mite. Currently there is no effective means to directly tackle the virus CiLV.

\subsection{Citrus Variegated Chlorosis (CVC)}

This is a disease caused by the bacterium Xylella fastidiosa [40, 41]. The proliferation of the bacterium in the xylem hinders the function of the vascular system in the plant, causing decreased vigor (such as leaf scorch and interveinal chlorosis) and growth and reduced fruit production. This bacterium can be transmitted by xylem-feeding leafhopper insects (so-called sharpshooters) Homalodisca vitripennis and Graphocephala atropunctata between plants, or through grafting of infected plants [4244]. Xylella fastidiosa inflicts many plants including citrus species, but severity varies; much more severe damages occur to sweet orange cultivars than grapefruit, limes or mandarins, while other varieties such as citron, lemon, pummelo and Rangpur lime are CVC tolerant. CVC has been found only in Brazil, Argentina and Paraguay so far [45].

Unlike the phloem-limited citrus green disease (HLB, see below), the pathogen $X$. fastidiosa survives only in plant xylem or within its insect vectors. Naturally, $X$. fastidiosa can be transmitted via infected propagative material or by insect vectors. It cannot be transmitted from citrus seeds to seedlings. The sharpshooters can quickly acquire $X$. fastidiosa from feeding on infected xylem and retain infectivity indefinitely. But they do not pass the bacterium onto the next generation $[45,46]$. Interestingly, $X$. fastiodiosa breaks down the pit membranes of xylem through enzymatic degradation, thereby overcoming the physical barrier of the small size of xylem fiber cells and achieving systemic colonization in xylem tissue [47]. No ideal treatment for CVC is available. Eradication of infected citrus trees via burning, chipping, or landfill burial is often recommended [48]. Exclusively using pathogen-free budwood for the propagation of nursery stock and grafting newly sprouted shoots with healthy buds is a fundamental component of CVC prevention [48, 49]. The $X$. fastidiosa genome has been sequenced 
([50]; Table 2), presenting technical opportunities for early detection by qPCR and future development of treatments specifically targeting its gene expression.

\subsection{Citrus Greening Disease (Huanglongbing)}

Citrus greening disease, also known as Huanglongbing (in Chinese meaning yellow dragon disease or yellow shoot disease, abbreviated HLB), is a destructive bacterial infection affecting citrus plants. Candidatus Liberibacter asiaticus (CLas) is widely believed to be the bacterial agent responsible for the disease in the United States. CLas and its related strains, Ca. L. americanus (CLam) and Ca. L. africanus (CLaf), are transmitted by the vectors Asian citrus psyllid Diaphorina citri Kuwayama and African citrus psyllid Trioza erytreae [51-53]. The bacterium CLas resides in the plant's phloem. When the psyllid feeds on a leaf of an infected citrus plant, it sucks up the nutrient-dense sap containing CLas bacteria from phloem. Psyllids then fly to the next uninfected plant to repeat the process and spread the pathogen. CLas proliferates within the phloem, thus blocking the transportation system and causing stunted growth, premature and lopsided greening fruit and yellow shoots, and eventual death (Figure 1). Citrus greening disease (HLB) has caused devastating economic damage to the citrus industry worldwide and has become an existential threat to Florida citrus production [10].

A

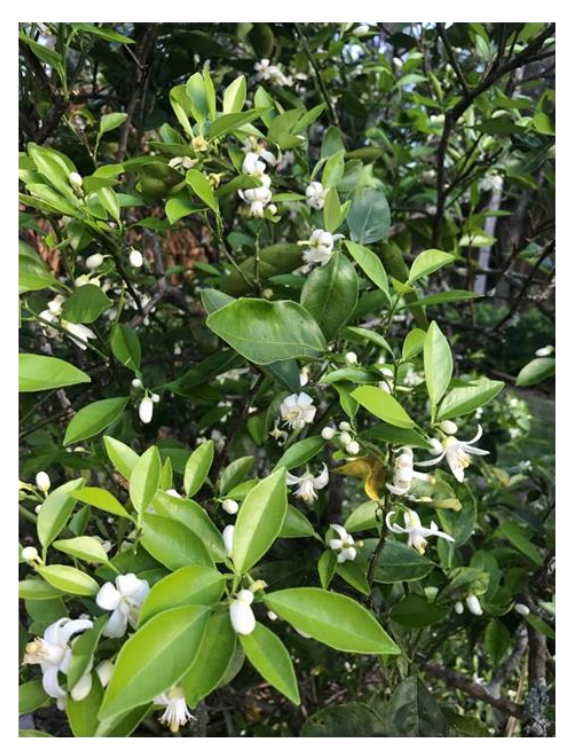

Healthy
B

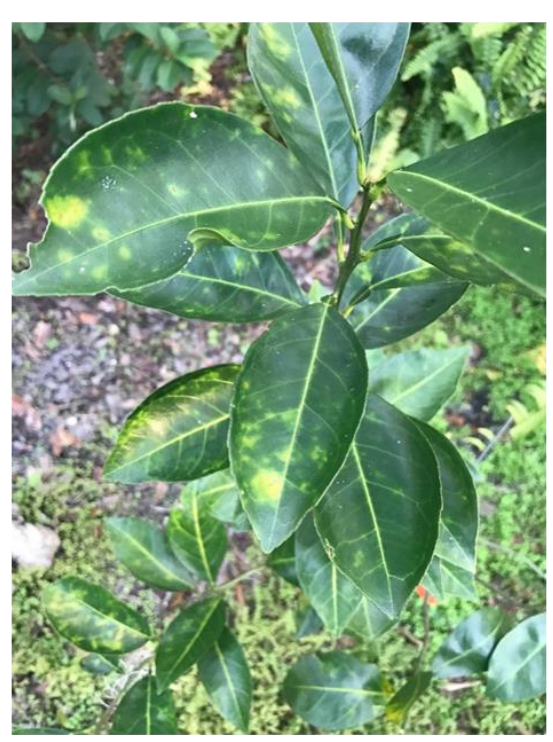

HLB

Figure 1 Citrus plants (sweet orange) under HLB attack. A: healthy-looking leaves (but already may have low titer CLas infection); B: HLB diseased leaves.

\subsection{Genetic Analysis of Citrus Greening Disease (HLB)}

More than a half-century of research and effort have been allotted toward the management of HLB. Various measures have been attempted to control HLB, such as insecticides ([54]), reflective mulch repellent [55], thermotherapy [56-60], fertigation [54, 61] and bactericides/antibiotics [60, 62-64] and 
viral/RNAi $[65,66]$ treatments. A genetic transformation approach has also been explored to create transgenic citrus scions [67] or transgenic plants [68] that are resistant to HLB and other citrus diseases. Direct injection to the phloem of an antimicrobial peptide from lime plants [69] or a plant extract concoction called Agent $\mathrm{G}$ ([70] and our unpublished observations) has shown a promising and safe way in treating and preventing HLB. However, there is currently not a single widely accepted regime of effective treatment or cure available. One of the major impediments to HLB research has been the inability to culture CLas bacteria despite all efforts $[10,71]$.

The genomes of several CLas strains have been sequenced (Table 3; [72, 73]). One immediate outcome of genomic sequencing is the realization of the detection of CLas bacteria by highly sensitive qPCR [74] using Clas-specific primers. qPCR detects the presence of CLas bacterial DNA in plant DNA extracts, thus indicating the bacterial infection even before HLB symptoms appear [70, 75-78]. More sensitive and specific primers for CLas detection have been developed. For example, primers of the multiple tandem-repeats of prophage genes [75] or the 5-copy $n r d B$ genes encoding the $\beta$-subunit of ribonucleotide reductase (RNR) $[79,80]$ have shown significantly increased PCR sensitivity. Moreover, RNR is more specific to CLas populations than the often used primers from 16S rRNA genes [79]. On the other hand, low titer and erratic distribution of CLas pathogen, especially during early stage of infection, may still lead to false negative diagnosis despite qPCR's sensitivity. This problem can be alleviated by testing more samples located across the plant.

Table 3 Candidatus Liberibacter asiaticus genomic data retrieved from citrusgenomedb.org.

\begin{tabular}{lccc}
\hline CLas strain & Genome size* & GC content & Number of genes \\
\hline gxpsy & $1.26 \mathrm{Mbp}$ & $36.30 \%$ & 1,147 \\
psy62 & $1.23 \mathrm{Mbp}$ & $36.50 \%$ & 1,100 \\
A4 & $1.23 \mathrm{Mbp}$ & $36.40 \%$ & 1,110 \\
Ishi-1 & $1.19 \mathrm{Mbp}$ & $36.32 \%$ & 1,064 \\
JXGC & $1.23 \mathrm{Mbp}$ & $36.40 \%$ & 1,120 \\
\hline
\end{tabular}

* Mbp: $10^{6}$ base pairs

With the availability of citrus and CLas genomic sequences, qPCR has also become an effective tool for gene expression analysis for both the pathogen and the infected host plant. Citrus plants respond to CLas infection and HLB with marked changes in gene expression. Liao and Burns [81] examined transcriptomic changes in fruit tissues of two sweet orange cultivars inflicted with HLB. Most genes that changed their expression patterns in the diseased tissues were related to transporters or carbohydrate metabolism. For example, in HLB-positive trees, gene expression in fruit tissues for glucose-6-P transporter, carbohydrate/sugar: $\mathrm{H}^{+}$symporter and Zinc transporter were all down-regulated, whereas gene expression for a sulphate transporter, cell wall/vacuolar inhibitor of fructosidase and Rubisco were up-regulated. This study illustrates the intricate interactions between the citrus plant host and the infectious CLas bacteria. Understanding of genetic and biochemical mechanisms of plants' response to CLas infection will help develop and implement measures of HLB treatment and control. 
On the other hand, the CLas genome sequence reveals the presence of prophages, reflecting the natural interactions between bacteria and viruses. The expression of CLas phage genes such as holin and peroxidases was found to be much lower in the natural host citrus plants having HLB than the CLasinfected non-host plant periwinkle [82]. In phenotypically healthy orange plants, some of the phage genes exhibited elevated expression [70]. These observations suggest a negative association between CLas phage activity and CLas virulence. This presents a tantalizing prospect of triggering CLas "suicide" by activating phage genes residing in the CLas genome to eliminate CLas bacteria and achieve a cure for HLB. Bacteriophages have been externally applied for control of citrus canker disease [30-32] and bacterial wilt disease in tomato [83]. Virus-based RNAi silence of CLas has also been tested as a treatment for HLB [64]. Activating endogenous prophage genes in CLas to initiate bacterial cell lysis would produce the similar outcome as a virulent bacteriophage.

Scanning electron microscopy (SEM) can also be used as an effective and reliable tool to visually examine phloem of infected plants, although SEM is unlikely to be a widely-used diagnostic application any time soon. HLB inflicted plants suffer from clogging of CLas bacterial colonies in the phloem (but not in the xylem). Using a simple freeze and fracture procedure [84], the leaf cross sections can be clearly imaged using SEM. This allows close observations of phloem and xylem tissues, revealing any blocking by bacterial aggregates in these transport tissues [70]. However, SEM images alone cannot identify which pathogen species causes the clogging of the plant vascular system.

We have employed both qPCR and SEM to examine CLas infection and monitor the treatment process for several citrus species/varieties. For example, using qPCR we assayed genomic DNA extracted from leaves of orange and lime plants grown in various locations in Florida. In our study, the identical primer sequences for elongation factor 1- $\alpha$ gene were chosen as a qPCR reference for sweet orange $(C . \times$ sinensis $)$, Persian lime $(C . \times$ latifolia $)$ and key lime $(C . \times$ aurantiifolia $)$ plants. To obtain more corroborate detection of CLas DNA, we independently examined three CLas gene targets (prophage tandem-repeats, elongation factor Ts and ribosomal protein L12P). As illustrated in Figure 2, the known HLB-inflicted orange plant (CSD) exhibited high levels of all three CLas genes tested, reflecting a relatively high dosage of the CLas bacteria. This is consistent with the severe HLB symptoms this plant displayed. As a negative control, the healthy orange plant (CSH) did not show signals for these CLas genes (Figure 2), indicating a CLas-free status in the leaf samples tested. In contrast, the lime plants (CLA-1, CLA-2, KL and $M L$ ) all revealed low but detectable levels of these CLas genes, even though they did not exhibit the typical HLB symptoms (as the diseased orange tree shown in Figure 1B). Sweet orange is known to be more susceptible to CLas than Persian lime and key lime. Our results may reflect lime plants' resistance to CLas infection. Low levels of CLas bacteria may not perpetuate serious HLB symptoms in lime plants. Therefore, the qPCR-based analysis can be a valuable tool for relatively early diagnosis of CLas infection status, regardless of appearance of any HLB phenotypes. 
A

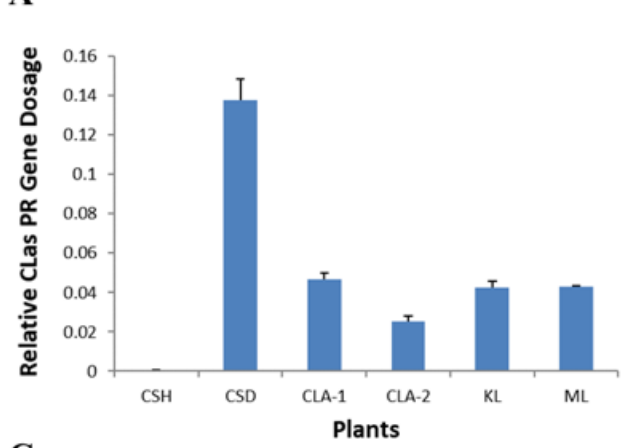

C

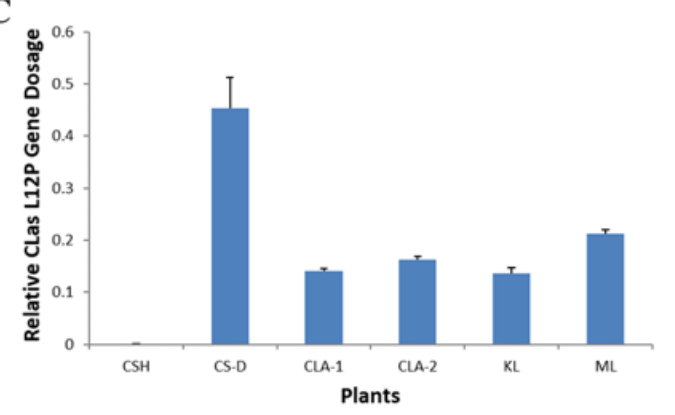

B

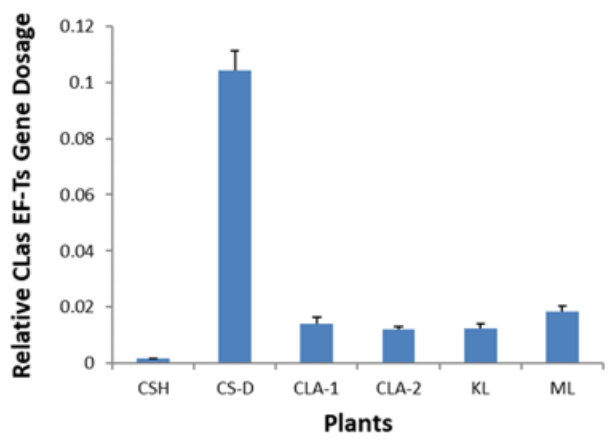

Figure 2 qPCR detection of CLas bacterial DNA in leaves of citrus plants. DNA was extracted from leaves of two sweet orange plants ( $C$. $\times$ sinensis, both located in Sarasota, Florida, USA) CSH (healthy, CLas-free from previous tests) and CSD (exhibiting HLB symptoms), two Persian lime (Citrus $\times$ latifolia) plants CLA-1 and CLA-2 (both located in Coconut Creek, Florida), and two key lime (C. $\times$ aurantiifolia) plants KL (located in Boca Raton, Florida) and ML (located in Davie, Florida). All lime plants did not show obvious disease symptoms, except for ML having signs of leaf damage by insect feeding. qPCR was done to detect CLas genes prophage repeat (PR; A), elongation factor Ts (EF-Ts; B) and ribosomal protein L12P (C). Sweet orange plant gene elongation factor $1-\alpha$ was used as a reference for $\Delta \mathrm{Ct}$ normalization [77]. The scale of $Y$-axis refers relevant ratio to the reference gene elongation factor 1- $\alpha$. The qPCR was performed using SYBR Green as described in [70]. Primer information is shown in Supplementary Table S1.

It should be pointed out that there may be a long and variable latent period from the time of the psyllids feeding on an infected citrus to the time of qPCR detection. By the time of a positive confirmation of CLas by qPCR, the psyllids have likely transmitted the bacterium from this source tree to numerous other trees. Furthermore, many factors such as cultivar susceptibility, climate conditions and horticultural practices can all affect CLas proliferation and colonization in the plant. Therefore, qPCR assay needs to be carried out early and often on well representative samples. Even so, qPCR detection may not be early enough to prevent CLas spread, but can be a valuable tool for infection monitoring and management.

We also examined these same citrus samples with SEM. As expected, the severely diseased orange plant showed extensive clogging deposits in the phloem sieve tube cells (Figure 3A), presumably by CLas colonization, which is corroborated with the qPCR results (CSD in Figure 2). Likewise, the SEM 
imaging of four lime trees revealed only sporadic presence of deposits and most of the sieve tubes appeared clear (Figure 3B-E). These observations are consistent with the healthy phenotypes of these plants as well as the trace level of CLas bacteria detected by the highly sensitive qPCR (Figure 2), suggesting that CLas had not yet proliferated enough to clog the sieve elements of the phloem. Therefore, a concerted effort of qPCR assay and SEM imaging, as well as other detection methods such as by canines [85] and serological detection of secreted CLas surface proteins [86] and host proteins secrete in phloem of CLas-infected trees [87], should serve as a reliable early diagnostic approach to citrus HLB.
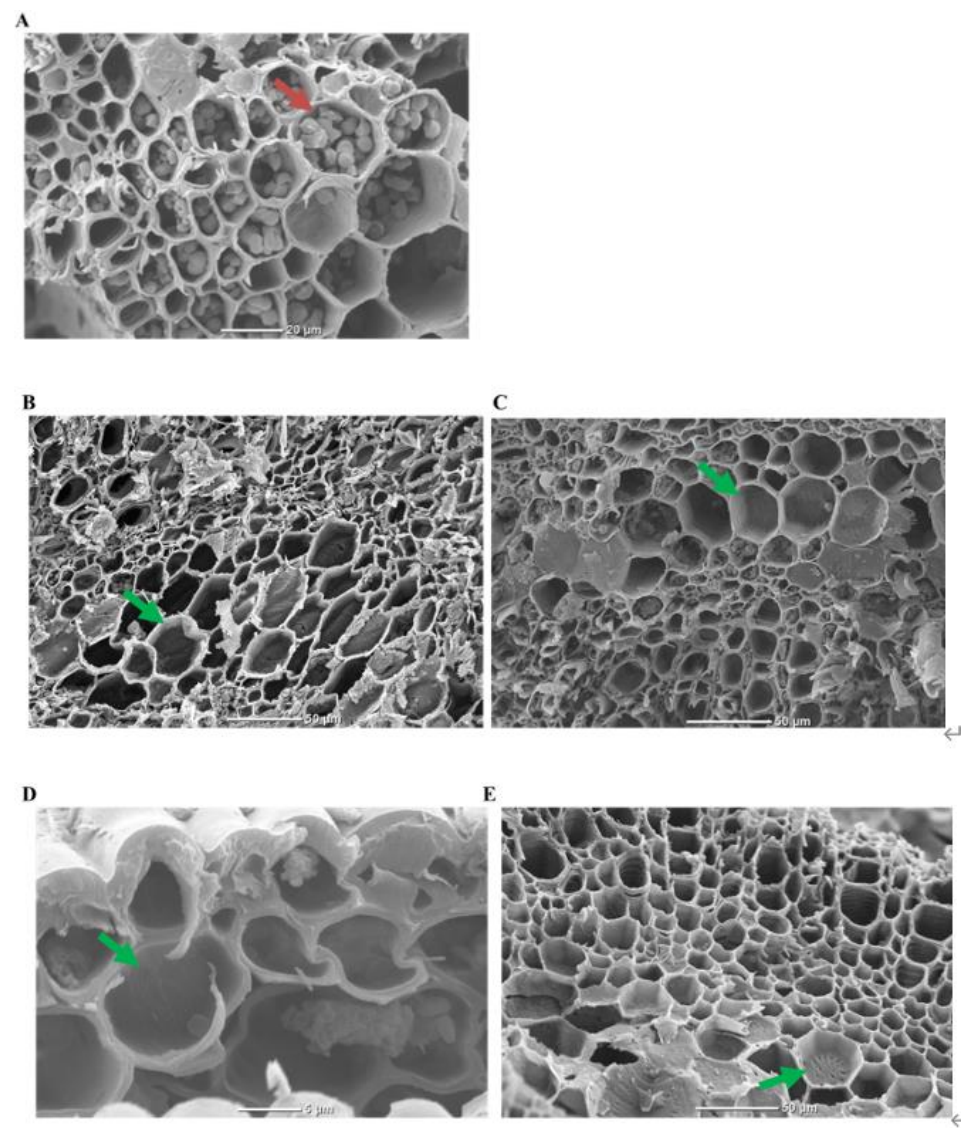

Figure 3 Scanning electron microscopic analysis of citrus leaves. Leaves were fixed in glutaraldehyde and dehydrated in a series of ethanol concentrations, followed by fracturing in liquid nitrogen. Leaf cross-sections were imaged by scanning electron microscopy. Leaf samples were collected from the same trifoliate leaves used for qPCR (Figure 1). A. Sweet orange CSD at magnification of $\times 850$. B. Lime CLA1 at magnification of $\times 400$. C. Lime CLA2 at magnification of $\times 450$. D. Lime KL at magnification of $\times 3,400$. E. Lime $M L$ at magnification of $\times 440$. Widespread bacterial clumps were observed in the phloem sieve tube cells of the HLB-inflicted sweet orange plant CSD (A). An example of clogged representative sieve cell is indicated with a red arrow. The visually healthy lime plants (B-E) had mostly clear sieve tube cells as representatively indicated with green arrows. Sample description is detailed in Figure 1. The SEM was done as described in [70]. 


\section{Concluding Remark}

Many plant diseases are caused by bacterial or viral pathogens and have inflicted tremendous damages to citrus production. Understanding the genomics and gene regulation for both the plants and the disease-causing pathogens is the key to develop effective tools for detection, monitoring, management and treatment of these diseases. Availability of genome sequences from many citrus species and cultivars has greatly advanced the pre-symptom detection and diagnosis of citrus diseases and paved way for genetic or metabolic engineering approaches for disease resistance and treatment. The rapidly expanding technological toolbox for genetic and biochemical analysis will empower future effort to combat these destructive citrus diseases and help protect and restore the citrus industry worldwide.

\section{Acknowledgement}

The authors thank Mark Myers for donating a lime sample (ML), Justin Kirke for assistance with qPCR analysis, and Jasmine Coyle and A.D. Henderson University School, Florida Atlantic University (FAU) Owls Imaging Lab for help with scanning electron microscopy work. This work was supported in part by a fund from Penta5, USA. Mohamed Abutineh and Nicholas Pizzo were awarded an FAU undergraduate research grant.

\section{Author Contributions}

$\mathrm{XHZ}$ and $\mathrm{JMH}$ conceived and directed this project. MA, NP, NN, XLJ and XHZ performed the experiments and analyzed the data. MA, NP and XHZ performed literature and database searches and wrote the manuscript. All commented on the manuscript.

\section{Competing Interests}

All authors declare no competing interest.

\section{References}

1. Swingle WT, Reece PC. The Citrus Industry. Revised 2nd ed. V. 1. History, World Distribution, Botany, and Varieties. Oakland, CA: University of California, Division of Agricultural Sciences; 1967.

2. Wu GA, Terol J, Ibanez V, López-García A, Pérez-Román E, Borredá C, et al. Genomics of the origin and evolution of Citrus. Nature. 2018; 554: 311-316.

3. Global citrus outlook [Internet]. World Citrus Organisation. Available from: https://worldcitrusorganisation.org/wp-content/uploads/2020/01/Citrus-Market-Trends2019.pdf.

4. Talon M, Wu GA, Gmitter Jr FG, Rokhsar DS. The origin of citrus. in The Genus Citrus. Sawston, UK: Woodhead Publishing; 2020. 
5. Beattie GA, Holford P, Mabberley DJ, Haigh AM, Broadbent P. On the origins of citrus, Huanglongbing, Diaphorina citri and Trioza erytreae. Proceedings of the International Research Conference on Huanglongbing; 2008 December 1; Orlando, FL, US. Exeter: Citrus Mutual.

6. Deng X, Yang X, Yamamoto M, Biswas MK. Domestication and history. The Genus Citrus. Sawston, UK: Woodhead Publishing; 2020.

7. Market and Policy Analyses of Raw Materials, Horticulture and Tropical (RAMHOT) Products Team. Citrus Fruit - Fresh and Processed Statistical Bulletin 2016 [internet]. Rome: Food and Agriculture Organization of the United Nations; 2017. Available from: http://www.fao.org/3/ai8092e.pdf.

8. Citrus fruits 2018 summary [Internet]. Washington: United States Department of Agriculture, National Agricultural Statistics Service. 2018 August. Available from: https://www.nass.usda.gov/Publications/Todays_Reports/reports/cfrt0818.pdf.

9. Li BB, Smith B, Hossain MM. Extraction of phenolics from citrus peels: I. Solvent extraction method. Sep Purif Technol. 2006; 48: 182-188.

10. National Academies of Sciences, Engineering, and Medicine. A review of the citrus greening research and development efforts supported by the Citrus Research and Development Foundation. Washington, DC: The National Academies Press; 2018.

11. Norberg RP. Economic importance of Florida citrus [Internet]. Ft. Pierce, FL: Florida Citrus Mutual; 2008 April 22. Available from: http://www.flcitrusmutual.com/files/e47fe5d8-ef81-4c15-9.pdf.

12. Rouseff RL, Nagy S. Health and nutritional benefits of citrus fruit components. Food Technol. 1994; 48: $125-132$.

13. Ross SA, Ziska DS, Zhao K, ElSohly MA. Variance of common flavonoids by brand of grapefruit juice. Fitoterapia. 2000; 71: 154-161.

14. Gorinstein S, Leontowicz H, Leontowicz M, Krzeminski R, Gralak M, Martin-Belloso O, et al. Fresh Israeli Jaffa blond (Shamouti) orange and Israeli Jaffa red Star Ruby (Sunrise) grapefruit juices affect plasma lipid metabolism and antioxidant capacity in rats fed added cholesterol. J Agric Food Chem. 2004; 52: 4853-4859.

15. Benavente-Garcia O, Castillo J. Update on uses and properties of citrus flavonoids: New findings in anticancer, cardiovascular, and anti-inflammatory activity. J Agric Food Chem. 2008; 56: 6185-6205.

16. Tian $Q$, Miller EG, Ahmad $H$, Tang L, Patil BS. Differential inhibition of human cancer cell proliferation by citrus limonoids. Nutr Cancer. 2001; 40: 180-184.

17. Gmitter FG, Chen C, Machado MA, De Souza AA, Ollitrault P, Froehlicher $Y$, et al. Citrus genomics. Tree Genet Genomes. 2012; 8: 611-626.

18. Curk F, Garcia-Lor A, Snoussi $\mathrm{H}$, et al. New insights on limes and lemons origin from nuclear and cytoplasmic markers genotyping and targeted nuclear gene sequencing. Acta Horti. 2015; 1065 : 135-146.

19. Ollitrault P, Dambier D, Luro F, Duperray C. Nuclear genome size variations in Citrus. Fruits. 1994; 49: 390-393.

20. Wang $X, X u Y$, Zhang $S$, Cao L, Huang $Y$, Cheng J, et al. Genomic analyses of primitive, wild and cultivated citrus provide insights into asexual reproduction. Nat Genet. 2017; 49: 765-772. 
21. Wang L, He F, Huang Y, He J, Yang S, Zeng J, et al. Genome of wild mandarin and domestication history of mandarin. Mol Plant. 2018; 11: 1024-1037.

22. Gmitter Jr FG, Wu GA, Rokhsar DS, Talon M. The citrus genome. The Genus Citrus. 1st ed. Sawston, UK: Woodhead Publishing; 2020.

23. Aleza $P$, Juárez J, Hernández $M$, Pina JA, Ollitrault $P$, Navarro L. Recovery and characterization of a Citrus clementina Hort. ex Tan. 'Clemenules' haploid plant selected to establish the reference whole Citrus genome sequence. BMC Plant Biol. 2009; 9: 1-7.

24. Wu GA, Prochnik S, Jenkins J, Salse J, Hellsten U, Murat F, et al. Sequencing of diverse mandarin, pummelo and orange genomes reveals complex history of admixture during citrus domestication. Nat Biotechnol. 2014; 32: 656-662.

25. Xu Q, Chen LL, Ruan X, Chen D, Zhu A, Chen C, et al. The draft genome of sweet orange (Citrus sinensis). Nat Genet. 2013; 45: 59-66.

26. Gottwald TR, Graham JH, Schubert TS. Citrus canker: The pathogen and its impact. Plant Health Prog. 2002; 3: 15.

27. Graham JH, Gottwald TR, Riley TD, Achor D. Penetration through leaf stomata and growth of strains of Xanthomonas campestris in citrus cultivars varying in susceptibility to bacterial diseases. Phytopathology. 1992; 82: 1319-1325.

28. Graham JH, Gottwald TR, Cubero J, Achor DS. Xanthomonas axonopodis pv. citri: Factors affecting successful eradication of citrus canker. Mol Plant Pathol. 2004; 5: 1-15.

29. Ference CM, Gochez AM, Behlau F, Wang N, Graham JH, Jones JB. Recent advances in the understanding of Xanthomonas citri ssp. citri pathogenesis and citrus canker disease management. Mol Plant Pathol. 2018; 19: 1302-1318.

30. Jones JB, Jackson LE, Balogh B, Obradovic A, Iriarte FB, Momol MT. Bacteriophages for plant disease control. Annu Rev Phytopathol. 2007; 45: 245-262.

31. Balogh B, Canteros BI, Stall RE, Jones JB. Control of citrus canker and citrus bacterial spot with bacteriophages. Plant Dis. 2008; 92: 1048-1052.

32. Balogh B, Jones JB, Iriarte FB, Momol MT. Phage therapy for plant disease control. Curr Pharm Biotechnol. 2010; 11: 48-57.

33. Bar-Joseph M, Marcus R, Lee RF. The continuous challenge of Citrus tristeza virus control. Annu Rev Phytopathol. 1989; 27: 291-316.

34. Lee RF. Control of virus diseases of citrus. Adv Virus Res. 2015; 91: 143-173.

35. Yokomi RK, Lastra R, Stoetzel MB, Damsteegt VD, Lee RF, Garnsey SM, et al. Establishment of the brown citrus aphid (Homoptera: Aphididae) in Central America and the Caribbean Basin and transmission of Citrus tristeza virus. J Econ Entomol. 1994; 87: 1078-1085.

36. Rodrigues JC, Kitajima EW, Childers CC, Chagas CM. Citrus leprosis virus vectored by Brevipalpus phoenicis (Acari: Tenuipalpidae) on citrus in Brazil. Exp Appl Acarol. 2003; 30: 161-179.

37. Locali EC, Freitas-Astua J, de Souza AA, Takita MA, Astua-Monge G, Antonioli R, et al. Development of a molecular tool for the diagnosis of leprosis, a major threat to citrus production in the Americas. Plant Dis. 2003; 87: 1317-1321.

38. Campos FJ, Omoto C. Resistance to hexythiazox in Brevipalpus phoenicis (Acari: Tenuipalpidae) from Brazilian citrus. Exp Appl Acarol. 2002; 26: 243-251. 
39. Childers CC, Rodrigues JCV, Derrick KS, Achor DS, French JV, Welbourn WC, et al. Citrus leprosis in Florida and Texas: Past and present. Exp Appl Acarol. 2003; 30: 181-202.

40. Chang CJ, Garnier M, Zreik L, Rossetti V, Bové JM. Culture and serological detection of the xylemlimited bacterium causing citrus variegated chlorosis and its identification as a strain of Xylella fastidiosa. Curr Microbiol. 1993; 27: 137-142.

41. Lee RF, Beretta MJ, Hartung JH, Hooker ME, Derrick KS. Citrus variegated chlorosis: Confirmation of a Xylella fastidiosa as the causal agent. Summa Phytopathol. 1993; 19: 123-125.

42. Gottwald TR, Gidtti FB, Santos JM, Carvalho AC. Preliminary spatial and temporal analysis of citrus variegated chlorosis (CVC) in Brazil. Proceedings of 12th Conference of International Organization of Citrus Virologists. 1993; Riverside, CA. Oakland: California Digital Library.

43. Roberto SR, Coutinho A, Lima JEO, Miranda VS, Carlos EF. Transmission of Xylella fastidiosa by the sharpshooters Dilobopterus coslalimai, Acrogonia terminalis and Oncometopia facialis in citrus. Fitopatol Bras. 1996; 21: 517-518.

44. Rapicavoli J, Ingel B, Blanco-Ulate B, Cantu D, Roper C. Xylella fastidiosa: An examination of a reemerging plant pathogen. Mol Plant Pathol. 2018; 19: 786-800.

45. Coletta-Filho HD, Castillo Al, Laranjeira FF, de Andrade EC, Silva NT, de Souza AA, et al. Citrus variegated chlorosis: An overview of 30 years of research and disease management. Trop Plant Pathol. 2020; 45: 175-191.

46. Killiny N, Almeida RP. Factors affecting the initial adhesion and retention of the plant pathogen Xylella fastidiosa in the foregut of an insect vector. Appl Environ Microbiol. 2014; 80: 420-426.

47. Mollenhauer HH, Hopkins DL. Ultrastructural study of Pierce's disease bacterium in grape xylem tissue. J Bacteriol. 1974; 119: 612-618.

48. Brlansky R, Davis M, Mizell R, Mossler M, Chang CJ, et al. Recovery plan for citrus variegated chlorosis caused by Xylella fastidiosa (CVC strain) [Internet]. Beltsville, MD, US: USDA Agricultural Research Service (ARS); 2008 October 14. Available from: https://www.ars.usda.gov/ARSUserFiles/opmp/Citrus\%20CVC\%20110408.pdf.

49. Lopes SA. Scion substitution: A new strategy to control citrus variegated chlorosis disease. Plant Dis. 2020; 104: 239-245.

50. Simpson AJ, Reinach FD, Arruda P, Abreu FA, Acencio M, Alvarenga R, et al. The genome sequence of the plant pathogen Xylella fastidiosa. Nature. 2000; 406: 151-157.

51. Bové JM. Huanglongbing: A destructive, newly-emerging, century-old disease of citrus. J Plant Pathol. 2006; 88: 7-37.

52. Gottwald TR, Graça JV, Bassanezi RB. Citrus huanglongbing: The pathogen and its impact. Plant Health Prog. 2007; 8: 31.

53. Halbert SE, Manjunath KL. Asian citrus psyllids (Sternorrhyncha: Psyllidae) and greening disease of citrus: A literature review and assessment of risk in Florida. Fla Entomol. 2004; 87: 330-353.

54. Tansey JA, Vanaclocha P, Monzo C, Jones M, Stansly PA. Costs and benefits of insecticide and foliar nutrient applications to huanglongbing-infected citrus trees. Pest Manag Sci. 2017; 73: 904-916.

55. Croxton SD, Stansly PA. Metalized polyethylene mulch to repel Asian citrus psyllid, slow spread of huanglongbing and improve growth of new citrus plantings. Pest Manag Sci. 2014; 70: 318-323. 
56. Hoffman MT, Doud MS, Williams L, Zhang MQ, Ding F, Stover E, et al. Heat treatment eliminates 'Candidatus Liberibacter asiaticus' from infected citrus trees under controlled conditions. Phytopathology. 2013; 103: 15-22.

57. Fan GC, Xia YL, Lin XJ, Hu HQ, Wang XD, Ruan CQ, et al. Evaluation of thermotherapy against Huanglongbing (citrus greening) in the greenhouse. J Integr Agric. 2016; 15: 111-119.

58. Doud MM, Wang Y, Hoffman MT, Latza CL, Luo W, Armstrong CM, et al. Solar thermotherapy reduces the titer of Candidatus Liberibacter asiaticus and enhances canopy growth by altering gene expression profiles in HLB-affected citrus plants. Hort Res. 2017; 4: 17054.

59. Etxeberria E, Gonzalez P, Vincent C, Schumann A. Extended persistence of Candidatus Liberibacter asiaticus (CLas) DNA in Huanglongbing-affected citrus tissue after bacterial death. Physiol Mol Plant Pathol. 2019; 106: 204-207.

60. Yang C, Powell CA, Duan Y, Shatters RG, Lin Y, Zhang M. Mitigating citrus huanglongbing via effective application of antimicrobial compounds and thermotherapy. Crop Prot. 2016; 84: 150158.

61. Morgan KT, Rouse RE, Ebel RC. Foliar applications of essential nutrients on growth and yield of 'Valencia' sweet orange infected with Huanglongbing. HortScience. 2016; 51: 1482-1493.

62. Zhang M, Guo Y, Powell CA, Doud MS, Yang C, Duan Y. Effective antibiotics against 'Candidatus Liberibacter asiaticus' in HLB-affected citrus plants identified via the graft-based evaluation. PloS ONE. 2014; 9: e111032.

63. Hu J, Wang N. Evaluation of the spatiotemporal dynamics of oxytetracycline and its control effect against citrus Huanglongbing via trunk injection. Phytopathology. 2016; 106: 1495-1503.

64. McVay J, Sun X, Jones D, Urbina H, Aldeek F, Cook JM, et al. Limited persistence of residues and metabolites in fruit and juice following penicillin trunk infusion in citrus affected by Huanglongbing. Crop Prot. 2019; 125: 104753.

65. Hajeri S, Killiny N, El-Mohtar C, Dawson WO, Gowda S. Citrus tristeza virus-based RNAi in citrus plants induces gene silencing in Diaphorina citri, a phloem-sap sucking insect vector of citrus greening disease (Huanglongbing). J Biotechnol. 2014; 176: 42-49.

66. Dawson WO, Bar-Joseph M, Garnsey SM, Moreno P. Citrus tristeza virus: Making an ally from an enemy. Annu Rev Phytopathol. 2015; 53: 137-155.

67. Wu H, Acanda Y, Shankar A, Peeples M, Hubbard C, Orbovic' V, et al. Genetic transformation of commercially important mature citrus scions. Crop Sci. 2015; 55: 2786-2797.

68. Dutt M, Barthe GA, Orbovic V, Irey M, Grosser JW. Evaluation of transgenic citrus for disease resistance to HLB and canker. Acta Hortic. 2015; 1065: 919-924.

69. Huang CY, Araujo K, Sánchez JN, Kund G, Trumble J, Roper C, et al. A stable antimicrobial peptide with dual functions of treating and preventing citrus Huanglongbing. Proc Natl Acad Sci U S A. 2021; 118: e2019628118.

70. Zhang XH, Pizzo N, Abutineh M, Jin XL, Naylon S, Meredith TL, et al. Molecular and cellular analysis of orange plants infected with Huanglongbing (citrus greening disease). Plant Growth Regul. 2020; 92: 333-343. 
71. Davis MJ, Mondal SN, Chen H, Rogers ME, Brlansky RH. Co-cultivation of 'Candidatus Liberibacter asiaticus' with actinobacteria from citrus with huanglongbing. Plant Dis. 2008; 92: 1547-1550.

72. Duan Y, Zhou L, Hall DG, Li W, Doddapaneni H, Lin H, et al. Complete genome sequence of citrus huanglongbing bacterium, 'Candidatus Liberibacter asiaticus' obtained through metagenomics. Mol Plant Microbe Interact. 2009; 22 :1011-1020.

73. Tyler HL, Roesch LF, Gowda S, Dawson WO, Triplett EW. Confirmation of the sequence of 'Candidatus Liberibacter asiaticus' and assessment of microbial diversity in Huanglongbinginfected citrus phloem using a metagenomic approach. Mol Plant Microbe Interact. 2009; 22: 16241634.

74. Tatineni S, Sagaram US, Gowda S, Robertson CJ, Dawson WO, Iwanami T, et al. In planta distribution of 'Candidatus Liberibacter asiaticus' as revealed by polymerase chain reaction (PCR) and real-time PCR. Phytopathology. 2008; 98: 592-599.

75. Morgan JK, Zhou L, Li W, Shatters RG, Keremane M, Duan YP. Improved real-time PCR detection of 'Candidatus Liberibacter asiaticus' from citrus and psyllid hosts by targeting the intragenic tandemrepeats of its prophage genes. Mol Cell Probes. 2012; 26: 90-98.

76. Lin H, Chen C, Doddapaneni H, Duan Y, Civerolo EL, Bai X, et al. A new diagnostic system for ultrasensitive and specific detection and quantification of Candidatus Liberibacter asiaticus, the bacterium associated with citrus Huanglongbing. J Microbiol Methods. 2010; 81: 17-25.

77. Li W, Hartung JS, Levy L. Quantitative real-time PCR for detection and identification of Candidatus Liberibacter species associated with citrus Huanglongbing. J Microbiol Methods. 2006; 66: 104-115.

78. Teixeira DC, Saillard C, Couture C, Martins EC, Wulff NA, Eveillard-Jagoueix S, et al. Distribution and quantification of Candidatus Liberibacter americanus, agent of huanglongbing disease of citrus in São Paulo State, Brasil, in leaves of an affected sweet orange tree as determined by PCR. Mol Cell Probes. 2008; 22: 139-150.

79. Zheng Z, Xu M, Bao M, Wu F, Chen J, Deng X. Unusual five copies and dual forms of $n r d B$ in "Candidatus Liberibacter asiaticus": Biological implications and PCR detection application. Sci Rep. 2016; 6: 39020.

80. Selvaraj V, Maheshwari Y, Hajeri S, Chen J, McCollum TG, Yokomi R. Development of a duplex droplet digital PCR assay for absolute quantitative detection of "Candidatus Liberibacter asiaticus". PIOS ONE. 2018; 13: e0197184.

81. Liao HL, Burns JK. Gene expression in Citrus sinensis fruit tissues harvested from Huanglongbinginfected trees: Comparison with girdled fruit. J Exp Bot. 2012; 63: 3307-3319.

82. Fleites LA, Jain M, Zhang S, Gabriel DW. “Candidatus Liberibacter asiaticus” prophage late genes may limit host range and culturability. Appl Environ Microbiol. 2014; 80: 6023-6030.

83. Wang $X$, Wei Z, Yang K, Wang J, Jousset A, Xu Y, et al. Phage combination therapies for bacterial wilt disease in tomato. Nat Biotechnol. 2019; 37: 1513-1520.

84. Haggis GH, Phipps-Todd B. Freeze-fracture for scanning electron microscopy. J Microsc. 1977; 111: 193-201. 
85. Gottwald T, Poole G, McCollum T, Hall D, Hartung J, Bai J, et al. Canine olfactory detection of a vectored phytobacterial pathogen, Liberibacter asiaticus, and integration with disease control. Proc Natl Acad Sci U S A. 2020; 117: 3492-3501.

86. Pagliaccia D, Shi JX, Pang ZQ, Hawara E, Clark K, Thapa SP, et al. A pathogen secreted protein as a detection marker for citrus Huanglongbing. Front Microbiol. 2017; 8: 2041.

87. Ding F, Duan Y, Yuan Q, Shao J, Hartung JS. Serological detection of 'Candidatus Liberibacter asiaticus' in citrus, and identification by GeLC-MS/MS of a chaperone protein responding to cellular pathogens. Sci Rep. 2016; 6: 29272.

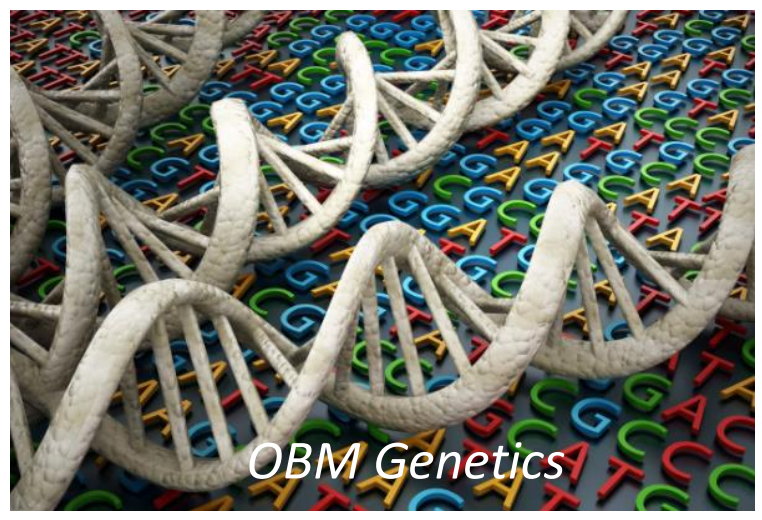

Enjoy OBM Genetics by:

1. Submitting a manuscript

2. Joining in volunteer reviewer bank

3. Joining Editorial Board

4. Guest editing a special issue

For more details, please visit:

http://www.lidsen.com/journals/genetics 